\title{
BITTER LEAF (VERNONIA AMYGDALINA) MODULATES NITROBENZENE-INDUCED RENAL DAMAGE IN RATS VIA SUPPRESSION OF OXIDO-INFLAMMATORY ACTIVITIES
}

Johnson Olaleye Oladele ${ }^{1}$, Oyedotun Moses Oyeleke ${ }^{1}$, Boyede Dele Olowookere ${ }^{1}$, Oluwafeyisayo Doyinsola Babatope ${ }^{1}$, Monisola Dorcas Olaniyan ${ }^{1}$, Blessing Oluwadunsin Akindolie ${ }^{1}$, and Oluwaseun Titilope Oladele ${ }^{2}$

${ }^{1}$ Department of Chemical Sciences, Faculty of Science,Kings University, Ode-Omu, Osun State, Nigeria ${ }^{2}$ Phytomedicine and Toxicology Laboratories, Department of Biochemistry, Faculty of Basic and Applied Sciences, Osun State University, Osogbo, Nigeria

\author{
GORKI LIST (VERNONIA AMIGDALINA) MODULIRA NITROBENZENOM \\ INDUKOVANO OŠTEĆENJE BUBREGA KOD PACOVA PREKO SUPRESIJE \\ OKSIIDO-INFLAMATORNIH AKTIVNOSTI \\ Johnson Olaleye Oladele ${ }^{1 *}$, Oyedotun Moses Oyeleke ${ }^{1}$, Boyede Dele Olowookere ${ }^{1}$, Oluwafeyisayo Doyinsola Babatope ${ }^{1}$ \\ Monisola Dorcas Olaniyan ${ }^{1}$, Blessing Oluwadunsin Akindolie ${ }^{1}$, and Oluwaseun Titilope Oladele ${ }^{2}$ \\ ${ }^{1}$ Departman za hemijske nauke, Prirodno-matematički fakultet, Kings Univerzitet, Ode-Omu, Država Osun, Nigerija \\ ${ }^{2}$ Laboratorija za fitomedicinu i toksikologiju, Departman za biohemiju, Fakultet za osnovne i primenjene nauke, \\ Univerzitet države Osun, Osogbo, Nigerija
}

\begin{abstract}
Renal diseases have been documented as one of the massive health challenges, ranked as the 12th most common cause of death globally. This study was carried out to assess the chemopreventive effects of Vernonia amydalina on nitrobenzene mediated renal damage in rats. Rats were exposed to $100 \mathrm{mg} / \mathrm{kg}$ body weight of nitrobenzene via oral administration and treated with $200 \mathrm{mg} / \mathrm{kg}$ body weight (BW) and $400 \mathrm{mg} / \mathrm{kg} \mathrm{BW}$ of methanol leaf extract of Vernonia amydalina (MLVA) and Vitamin E for 14 consecutive days. Nitrobenzene significantly induced a renal injury with a significant increase in the serum levels of urea and creatinine with the concomitant altered serum electrolyte profile. Also, nitrobenzene mediated the oxidative stress and lipid peroxidation with a significant increase in the renal level of malondialdehyde $(\mathrm{MDA})$, hydrogen peroxide $\left(\mathrm{H}_{2} \mathrm{O}_{2}\right)$, with a concomitant decrease in the level of reduced glutathione (GSH), Catalase (CAT) and Superoxide dismutase (SOD). Furthermore, an inflammation was observed in the nitrobenzene-treated rats with the elevated level of nitric oxide (NO) and myeloperoxidase (MPO). However, the treatment with methanol leaf extract of Vernonia amydalina reversed all the nitrobenzene-associated renal damage, electrolyte imbalance, oxidative stress, lipid peroxidation, inflammation and altered antioxidant defence system. Taken together, methanol leaf extract of Vernonia amydalina offers protection which may be beneficial for the treatment and management of kidney diseases or other related disorders via enhancing the serum electrolyte homeostasis, protecting the structural integrity of the kidney, antioxidant, anti-inflammatory mechanisms.
\end{abstract}

Keywords: Renal damage, Nitrobenzene, oxidative stress, Vernonia amydalina, Inflammation, Electrolyte imbalance

\section{sciendo}

UDK: 615.322:582

616.61-085 $2021 ; 22(4): 317-324$

DOI: $10.2478 /$ sjecr-2020-0040

\section{SAŽETAK}

Za bubrežne bolesti je dokazano da su jedan od najvećih zdravstvenih izazova i zauzimaju 12. mesto među najčešćim uzrocima smrtnosti na globalnom nivou. Ova studija je izvedena kako bi procenila hemo-preventivne efekte Vernonia amigdaline kod nitrobenzenom indukovanog ostećenja bubrega kod pacova. Pacovi su bili izloženi $100 \mathrm{mg} / \mathrm{kg}$ telesne težine, nitrobenzenu preko oralne primene i tretirani sa $200 \mathrm{mg} / \mathrm{kg}$ telesne težine $i 400$ $\mathrm{mg} / \mathrm{kg}$ telesne težine sa metanolnim ekstraktom lista Vernonie amigdaline (MLVA) i vitaminom E, 14 uzastopnih dana. Nitrobenzen je značajno izazvao oštećenje bubrega sa znatnim povećanjem serumskih nivoa uree i kreatinina sa istovremenim izmenjenim serumskim elektrolitnim profilom. Takođe, nitrobenzen posreduje $u$ oksidativnom stresu $i$ lipidnoj peroksidaciji sa značajnim povećanjem nivoa malondialdehida (MDA) u bubrezima, vodonik peroksida $\left(\mathrm{H}_{2} \mathrm{O}_{2}\right)$, sa istovremenim smanjenjem $u$ nivou smanjenog glutationa (GSH), katalaze (CAT) i superoksid dismutaze (SOD). Osim toga, zapaljenje je bilo primećeno kod pacova tretiranih nitrobenzenom sa povišenim nivoom azotnog oksida (NO) i mijeloperoksidaze (MPO). Međutim, tretman sa metanolnim ekstraktom lista Vernonie amigdaline promenio je celokupno oštećenje bubrega povezano sa nitrobenzenom, neravnotežu elektrolita, oksidativni stres, lipidnu peroksidaciju, inflamaciju i izmenjeni antioksidativni odbrambeni system. Sve u svemu, metanolni ekstrakt lista Vernonie amigdaline pruža zaštitu koja može biti korisna za lečenje i tretiranje bolesti bubrega ili drugih povezanih poremećaja preko pospěsivanja serumske elektrolitne homeostaze, štiteći pri tome strukturni integritet bubrega, antioksidativne i anti-inflmatorne mehanizme.

Ključne reči: oštećenje bubrega, nitrobenzene, oksidativni stres, Vernonia amigdalina, inflamacija, neravnoteža elektrolita 


\section{INTRODUCTION}

Renal damage has been described as one of the massive health issues, the stream of which continues to rise unavoidably. In 2015, the report of Global Burden of Disease Study, the kidney disease was recorded as the 12th most common cause of death which accounts for 1.1 million deaths throughout the World (1). The total kidney damage mortality rate was also documented to have increased by $31.7 \%$ over the last 10 years making it one of the fastest increasing foremost causes of death, along with other diseases like diabetes and dementia. Renal damage has been recorded to be a major problem considered by morphological damage of intracellular organelles, cellular necrosis, mitochondrial vacuolization, followed by functional modifications which include a reduction in the synthesis of protein, reduced glutathione (GSH) depletion, lipid peroxidation (LPO) and mitochondrial damage (2).

Nitrobenzene (NB) has been regarded as one lethal air contaminant with a proven ability to cause cancer in animals. According to the 1986 Cancer guidelines, it was classified as a group B2 chemical, as likely a human carcinogen (3). It is water-insoluble pale-yellow oil with an almond odor like substances used in industry for making varieties of chemicals such as aniline, analgesics, dye, polish for shoes and other useful products. During the metabolism of NB, intermediates such as nitrosobenzene (NOB) and phenylhydroxylamine $(\mathrm{PH})$ are formed and play an important role in the progression of Nitrobenzene carcinogenesis (4). Certain high concentration of Nitrobenzene was also reported to be found in the liver, brain, blood and stomach following accidental nitrobenzene poisoning in humans (4).

Phytoextracts or their products have been reported to improve the kidney damage induced by free radicals, thereby protecting it against any forms of functional modifications and injury. This protection against the renal damage, and other reported pharmacological abilities like antioxidant, neuroprotective and anti-inflammatory activities validate the exhaustive scientific investigation into their nephroprotective properties (5). The herb known as bitter leaf (Vernonia amygdalina) is a shrub or small tree which is known to reach about 23 feet in height when fully grown. Bitter leaf is known for having a grey or brown coloured bark, which has a rough texture even when peeled. The herb is an indigenous African plant; which grows in most parts of the African continent (6). Bitter leaf (Vernonia amygdalina) has been reported to have hypoglycemic, anti-diabetic and anticholesterol properties $(7,8)$. Besides, the extract ameliorates haematotoxicity in rats exposed to petroleum hydrocarbon feeds (9).

Based on the aforementioned information, this study was carried out to examine the adverse effects of nitrobenzene in the kidney of Wistar albino rats via the evaluation of serum electrolytes, renal function tests, renal redox status, and postmortem histopathology of the renal tissue. Furthermore, we aimed to assess the ameliorative potentials of methanol leaf extract of Vernonia amygdalina against renal toxicities associated with nitrobenzene exposure.

\section{MATERIALS AND METHODS}

\section{Chemicals/ Reagents}

High purity ( $>99.7 \%$ ) Nitrobenzene was obtained from BDH chemical Poole England. Vitamin E (Alpha Tocopherol) is a product of Embassy pharmaceuticals, Nigeria. Urea, creatinine assay kits are diagnostic kits from Randox. All other chemicals are of the analytical grade and were obtained from Analar BDH Limited, Poole, England and Sigma-Aldrich Co. St Louis, Missouri, USA.

\section{Collection of plant material and preparation of extract}

Fresh leaves of Vernonia amygdalina were collected at the staff quarters in Kings University, Odeomu, Osun State. The leaf has been identified at IFE-Herbarium of Botany Department, Obafemi Awolowo University, Ile-Ife with Voucher number, IFE-16885. The Vernonia amygdalina leaves were washed and air-dried at room temperature in the Biochemistry laboratory, Kings University, Nigeria and pulverized using an electric blender. The powdered leaf was defatted in n-hexane using Soxhlet apparatus. Thereafter, methanol extract was prepared by soaking the defatted leaf in $90 \%$ methanol for 72 hours. The resulting mixture was then filtered and the filtrate was concentrated on water bath. The concentrated extract was lyophilized using Bosch freeze drying machine. The full chemical identification and bioactive compounds of Vernonia amygdalina have been earlier reported by Oladunmoye et al (10) using gas chromatographymass spectrometry (GC-MS). The technique reveals methyl2-O-benzyl-d-arabinofuranoside, phytol, hexadecanoic acid, ethyl ester, squalene and 9,12,15, octadecatrienoic acid as more abundant compounds ( $>85 \%$ abundance) while $\mathrm{N}-[2-$ (dimethylamino)-5-pyrimidinyl] benzene sulfonamide, 9, 12, 15 and octadecatrien-1-ol, p-Menth-4(8)-en-9-ol have lesser abundance $(<12 \%$ abundance) compounds.

\section{Experimental animals}

Thirty mature, 4-5 months old male Wistar strain albino rats with body weight range $140-160 \mathrm{~g}$ were used in the study. The rats were sourced and raised at the Biochemistry breeding colony of the Biochemistry Unit, Department of Chemical Sciences, Kings University, Ode-Omu, Osun State, Nigeria. The animals were kept under the ambient standard conditions $\left(25 \pm 2{ }^{\circ} \mathrm{C}\right.$ and relative humidity of $\left.50 \pm 15 \%\right)$ in stainless steel cages and metabolic wastes were cleaned twice daily. The rats were allowed to acclimatize to these conditions for fourteen days and were exposed to $12 \mathrm{hrs}$ daylight and darkness cycle, fed with commercially available rat pellet and water ad libitum. The experiment was carried out in accordance with the current rules and guidelines that have been established for the care of the laboratory animals (11). The rats were randomised into five groups containing six rats each. 
Group A: received distilled water daily and served as the Control.

Group B: received $100 \mathrm{mg} / \mathrm{kg}$ Nitrobenzene orally.

Group C: received $100 \mathrm{mg} / \mathrm{kg}$ Nitrobenzene and $200 \mathrm{mg} / \mathrm{kg}$ Vernonia amygdalina

Group D: received $100 \mathrm{mg} / \mathrm{kg}$ Nitrobenzene and $400 \mathrm{mg} / \mathrm{kg}$ Vernonia amygdalina

Group E: Received 100 mg/kg Nitrobenzene and 400 mg/kg Vitamin

The treatments were administered to the rats through oral gavage for 14 consecutive days.

\section{Preparation of liver homogenates}

The kidneys were immediately excised and blotted to remove blood stains. They were cleansed and rinsed in $1.15 \%$ $\mathrm{KCl}$ on ice to remove haemoglobin, then weighed. They were then chopped into bits and homogenized in four volumes of the homogenizing buffer $(10 \mathrm{mM}$ potassium phosphate buffer, $\mathrm{pH}$ 7.4) using a Teflon homogenizer. The homogenates were centrifuged at $12,500 \mathrm{~g}$ for 15 minutes in a cold centrifuge $\left(4^{\circ} \mathrm{C}\right)$ to obtain the post mitochondrial fractions which were collected and used for biochemical analyses.

\section{Measurement of biochemical markers}

The protein content of the homogenates was determined using Bovine Serum Albumin (BSA) as a standard in the protocol described by Lowry et al. (12). Urea, and creatinine acid were determined colometrically following the instruction of the assay kits manufacturer. The Nitric oxide (NO) level was assessed by the procedure reported by Green et al. (13). Myeloperoxidase (MPO) activity in the homogenate was quantified following the method of Granell et al. (14). Superoxide dismutase (SOD) activity was evaluated following the inhibition of adrenaline auto-oxidation in a basic milieu as described by Misra and Fridovich (15). Lipid peroxidation was evaluated by monitoring the level of malondialdehyde (MDA) using the procedure reported by Varshney and Kale (16). The reduced glutathione (GSH) content in the brain samples was determined using the protocol reported by Buetler et al. (17). Catalase (CAT) activity was determined following the protocol documented by Clairborne (18) using hydrogen peroxide $\left(\mathrm{H}_{2} \mathrm{O}_{2}\right)$ as a substrate. Hydrogen peroxide generation was assayed by oxidation of ferrous ions and sorbitol colour amplification system using the method of Wolff (19).

\section{Histological examination}

The kidney sections were fixed in $10 \%$ formalin and embedded in paraffin wax. Thin sections (7-9 mm thickness) of the kidney tissues were cut and dewaxed in xylene, hydrated in decreasing percentage of alcohol and stained with hematoxylin and eosin (H \& E). They were differentiated in 90\% alcohol and cleared in xylene. These stained sections were observed under the microscope for histopathological analysis.

\section{Statistical analysis}

The results obtained were expressed as the mean \pm standard deviation (mean \pm SD) and analysed using one-way analysis of variance (ANOVA) with the aid of SPSS 22.0 computer software package (SPSS Inc; Chicago, U.S.A) to compare the experimental groups followed by Bonferroni's posthoc test. Values of $\mathrm{P}<0.05$ were considered significant.

\section{RESULTS}

\section{Effects of MLVA on the serum electrolyte profile of rats treated with nitrobenzene}

Serum electrolytes profile levels in the experimental animals are shown in figure 1. Nitrobenzene exposure caused a significant increase in potassium ion and a significantly reduced sodium ion and bicarbonates as compared to the control. However, the treatment with 200 and $400 \mathrm{mg} / \mathrm{kg}$ body weight of MLVA or vitamin E caused a drastic reversal in the serum level of the electrolytes close to normal.

Figure 1. Effect of MLVA on the serum electrolyte profile of rats treated with nitrobenzene

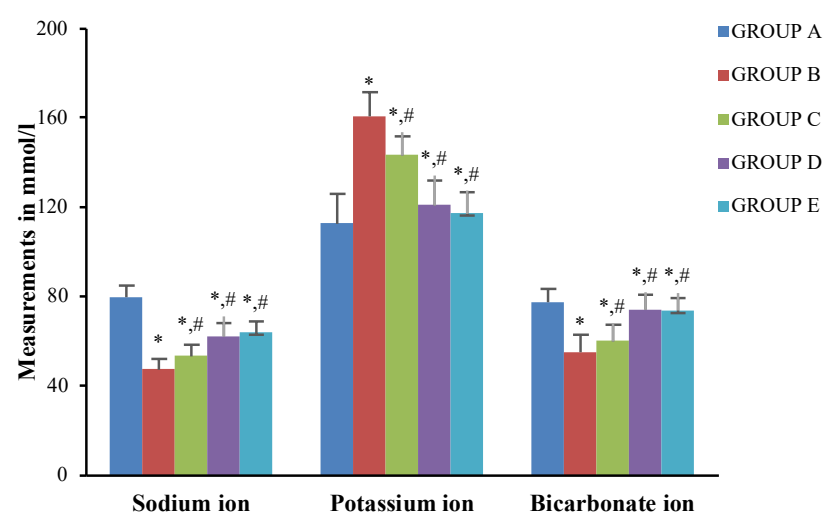

Data are given as the mean \pm SD of rats per group. $n=6$. MLVA: methanol leaf extract of Vernonia amygdalina, *: Values differ significantly from the group A (control) $(\mathrm{P}<$ $0.05)$. \#: Values differ significantly from the group $B$.

\section{Effects of MLVA on the serum renal metabolites of rats treated with nitrobenzene}

Figure 2 shows that the rats exposed to $100 \mathrm{mg} / \mathrm{kg}$ body weight of nitrobenzene (group B) showed a significant increase in the serum concentration levels of urea and creatinine as compared to the control (group A). The serum elevated values of urea and creatinine were reversed significantly toward normal in a dose dependent manner in the rats treated with 200 and $400 \mathrm{mg} / \mathrm{kg}$ body weight of MLVA or vitamin E. 
Figure 2. Effect of MLVA on the serum renal metabolites (urea and creatinine) in rats treated with nitrobenzene

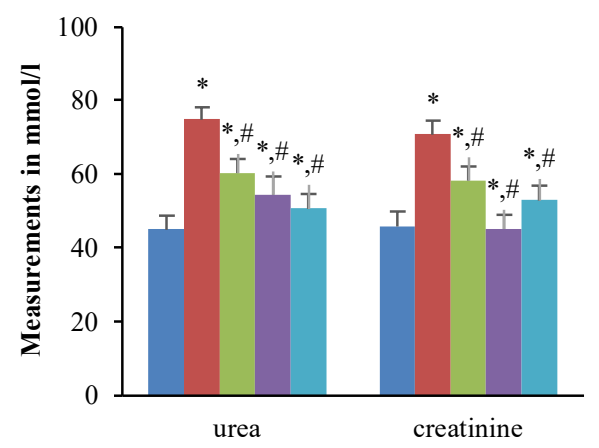

GROUP A

- GROUP B

GROUP C

-GROUP D

GROUP E

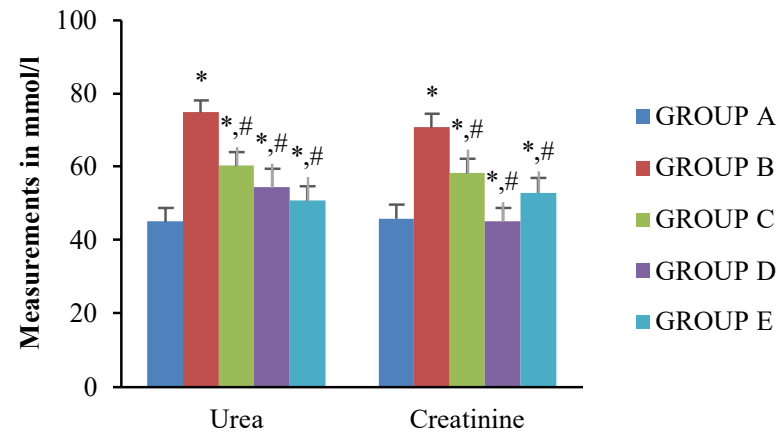

Data are given as the mean \pm SD of rats per group. $n=6$.

MLVA: methanol leaf extract of Vernonia amygdalina, *:

Values differ significantly from the group A (control) $(\mathrm{P}<0.05)$. \#: Values differ significantly from the group $\mathrm{B}$.

\section{MLVA mitigated oxidative stress in the kidney of rats treated with nitrobenzene}

Figure 3 showed the results of renal oxidative stress biomarker $\left(\mathrm{H}_{2} \mathrm{O}_{2}\right.$ generation) carried out in the experimental rats. There was a marked increase in the level of $\mathrm{H}_{2} \mathrm{O}_{2}$ generation in the kidney of rats that received nitrobenzene only when compared with the control group. Upon the treatment with 200 and $400 \mathrm{mg} / \mathrm{kg}$ of MLVA or Vitamin E, there was a significant decrease in $\mathrm{H}_{2} \mathrm{O}_{2}$ generation level confirming the free radical and ROS scavenging ability of the extract.

Figure 3. Effect of MLVA on the renal myeloperoxidase (MPO) and hydrogen peroxide generation $\left(\mathrm{H}_{2} \mathrm{O}_{2}\right)$ levels in rats treated with nitrobenzene.

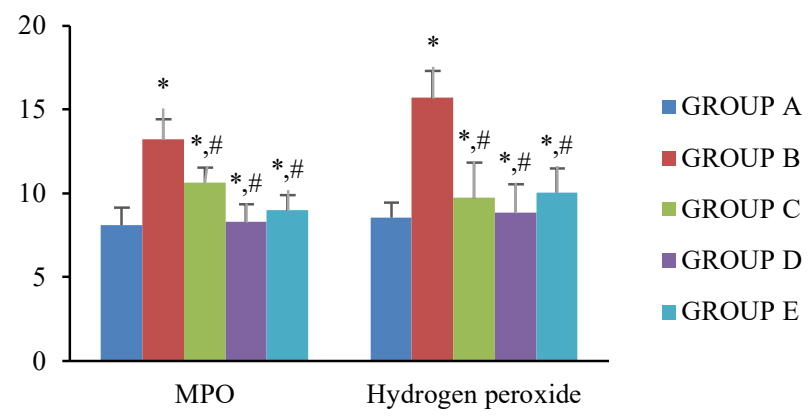

MPO activity (Units/mg protein); $\mathrm{H}_{2} \mathrm{O}_{2}$ ( $\mu$ mole/mg protein). Data are given as the mean \pm SD of rats per group. $n=6$. MLVA: methanol leaf extract of Vernonia amygdalina, *:

Values differ significantly from the group A (control) $(\mathrm{P}<0.05)$. \#: Values differ significantly from the group B.

\section{Effects of MLVA on the renal inflammatory markers of rats treated with nitrobenzene}

The effects of MLVA on inflammation in the kidney of the experimental rats were evaluated by measuring MPO activities and NO concentration level. The rats that received nitrobenzene only, demonstrated a marked increase in NO level and MPO activities when compared with the control (Figure 3 and 4). However, the treatment with 200 and $400 \mathrm{mg} / \mathrm{kg}$ of MLVA or Vitamin E significantly attenuated both NO and MPO levels in the kidney when compared with the control.

Figure 4. Effect of MLVA on the renal nitric oxide (NO) and Lipid peroxidation (LPO) level in rats treated with nitrobenzene

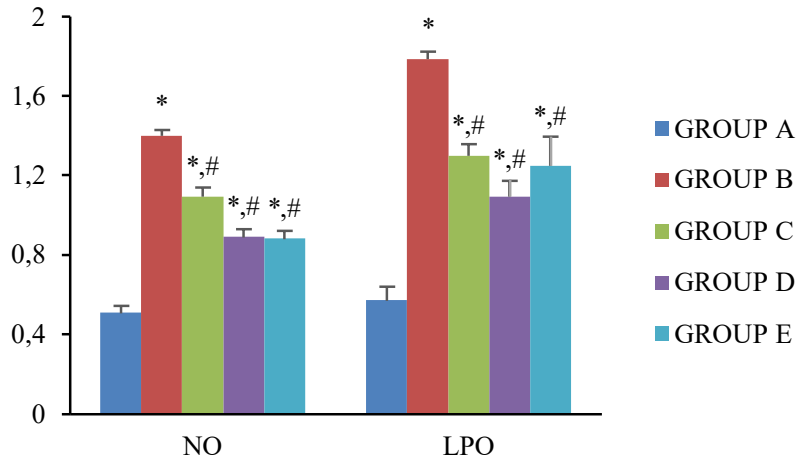

Lipid peroxidation ( $\mu \mathrm{mol} \mathrm{MDA} / \mathrm{mg}$ protein); NO level (Unit/mg protein). Data are given as the mean $\pm \mathrm{SD}$ of rats per group. $\mathrm{n}=6$. MLVA: methanol leaf extract of Vernonia amygdalina, *: Values differ significantly from the group A

(control) $(\mathrm{P}<0.05)$. \#: Values differ significantly from the group B.

MLVA inhibited lipid peroxidation in the kidney of rats treated with nitrobenzene

The result of renal lipid peroxidation assayed in this experiment was depicted in Fig. 4. There was a marked increase in MDA level (the index of lipid peroxidation) in the rats that received nitrobenzene only when compared with the control group. However, the treatment with 200 and $400 \mathrm{mg} / \mathrm{kg}$ of MLVA or Vitamin E inhibited the peroxidation with a significant decrease in MDA level.

Effects of MLVA on the reduced glutathione level and antioxidant enzymes activities in the kidney of rats treated with nitrobenzene

Figure 5-7 shows the glutathione (GSH) level and antioxidant enzymatic activities of CAT and SOD in the kidney of the experimental rats. The application of nitrobenzene alone caused a significant decrease in the GSH level and a decline 
in CAT and SOD activity when compared with the control. However, the treatment with 200 and $400 \mathrm{mg} / \mathrm{kg}$ of MLVA or Vitamin E significantly increased the GSH level and enhanced the activity of all the enzymes.

Figure 5. Effect of MLVA on the renal reduced glutathione level in rats treated with nitrobenzene

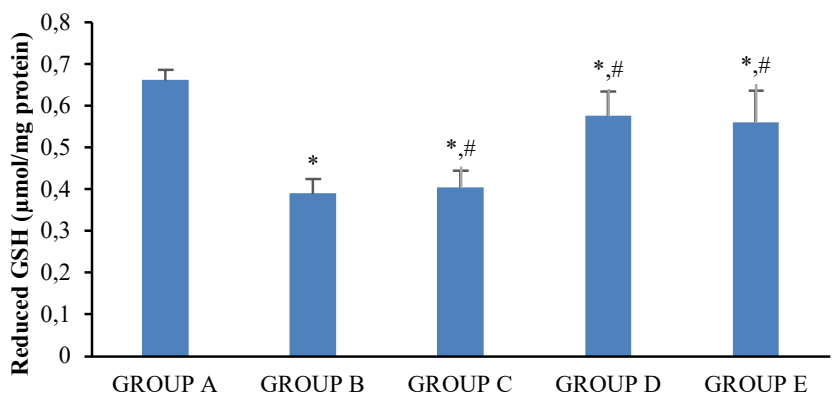

Data are given as the mean \pm SD of rats per group. $n=6$. MLVA: methanol leaf extract of Vernonia amygdalina, *:

Values differ significantly from the group A (control) $(\mathrm{P}<0.05)$. \#: Values differ significantly from the group $\mathrm{B}$.

Figure 6. Effect of MLVA on the renal superoxide dismutase (SOD) activities in rats treated with nitrobenzene.

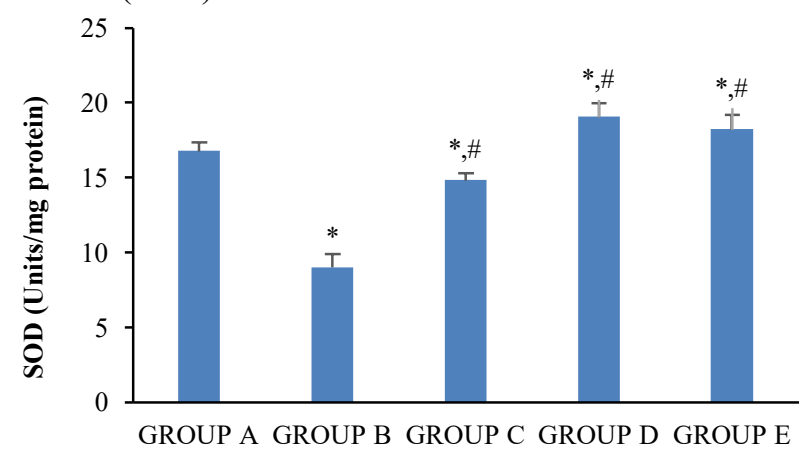

Data are given as the mean $\pm \mathrm{SD}$ of rats per group. $\mathrm{n}=6$.

MLVA: methanol leaf extract of Vernonia amygdalina, *:

Values differ significantly from the group A (control) $(\mathrm{P}<0.05)$. \#: Values differ significantly from the group B.

Figure 7. Effect of MLVA on the renal catalase (CAT) activities in rats treated with nitrobenzene

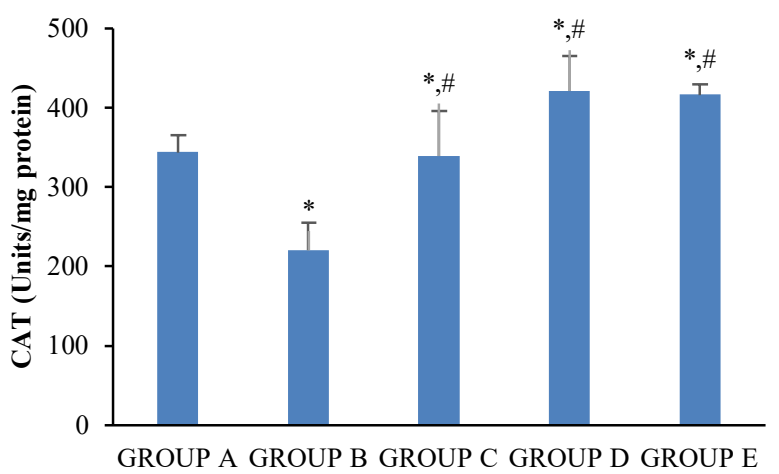

Data are given as the mean $\pm \mathrm{SD}$ of rats per group. $\mathrm{n}=6$. MLVA: methanol leaf extract of Vernonia amygdalina, *: Values differ significantly from the group A (control) $(\mathrm{P}<$ $0.05)$. \#: Values differ significantly from the group B.

Figure 8. Photomicrographs of the renal cortex showing the panoramic views of Kidney general micromorphological presentations in Adult Wistar rats across the study groups A-E. Hematoxylin and Eosin stain (X40 and X100 Magnification).

The Renal Corpuscles, Renal glomeruli, Macula densa, Distal and Proximal convoluted tubules and the Bowman's capsule are observable across the study groups.
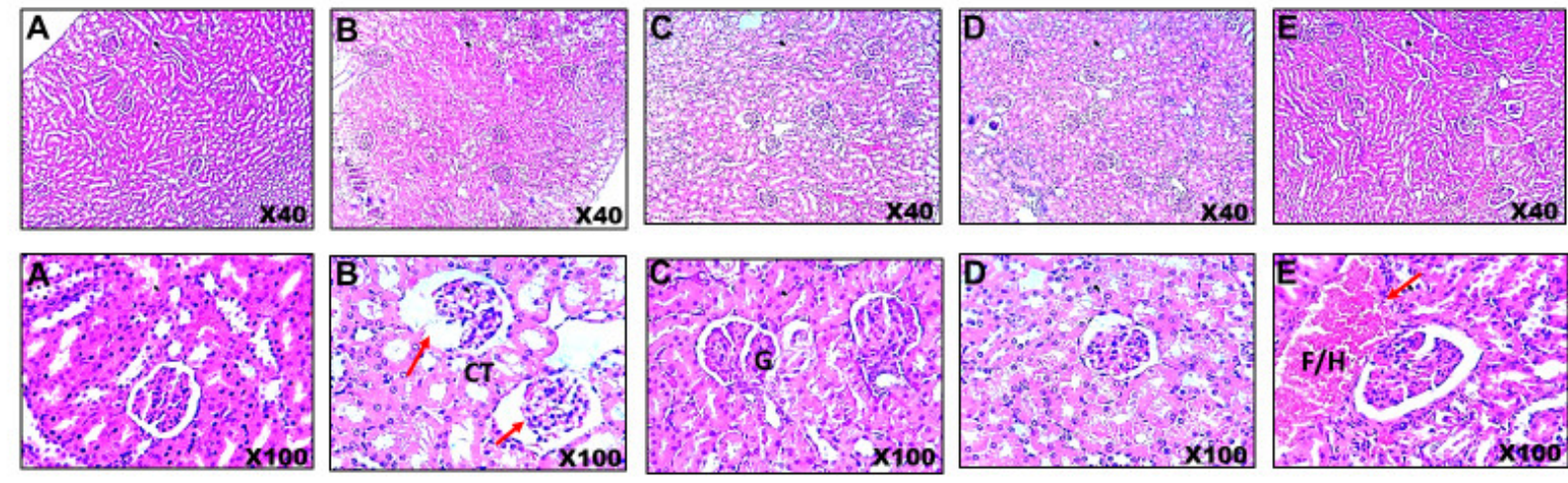

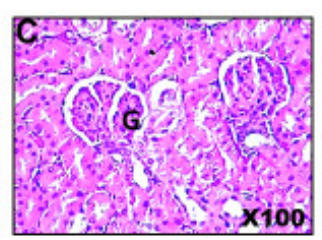

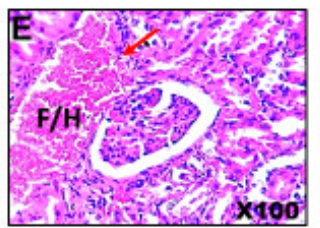


Protective effects of MLVA on the histological alterations in the kidney sections of nitrobenzene-induced renal damage in rats

The histological alterations seen with the light microscope in the kidney sections of the experimental rats are shown in Figure 8. The collagen of the parietal layer of Bowman's capsule and the basal membrane of a distal tubule are observable from the photomicrographs. The groups B and E showed mild fibrosis and haemorrhage characterized by presence of red inflammatory cells (red thick arrow) but no other varying degrees of the renal injury except for marked shrinkage of the glomerulus observable in the group B, the groups $\mathrm{A}$ and $\mathrm{D}$ showed no marked degenerative changes however, mild focal sclerosis of the glomerulus, mild widening of the Bowman's space and hyper cellularity are all observable across the groups B, C and E. There is no observable hyaline arteriosclerosis, no observable interstitial fibrosis, no interstitial inflammation observed across the groups A and D. The areas of pathomorphological observations are indicated by red arrows.

\section{DISSCUSION}

The role played by the kidneys in maintaining the balance of fluid and electrolytes in the serum becomes clear when considering the consequences on electrolytes in the rats with the acute renal failure. The levels of electrolytes such as potassium, sodium, magnesium, calcium and bicarbonates can all be affected and lead to an array of signs and symptoms. When there is a malfunction of the kidneys, the balance of fluid and electrolytes levels can be altered, leading to the imbalance of certain electrolytes resulting in serious implications or consequences (20).

In this study, the serum level of sodium and bicarbonate ions was significantly decreased due to the exposure of nitrobenzene to the experimental rats. The concentration of these electrolytes is essential for maintaining the fluid and acidbase balance and for proper renal function (21). Healthy kidneys alter the excretion of sodium in the urine to prevent certain diseases like hypernatremia. However, the administration of various concentrations of methanol leaf extract of Vernonia amygdalina or Vitamin E significantly increased the serum levels of both sodium and bicarbonate ions levels. This result suggests that the extract can enhance the electrolyte homeostasis and may be beneficial in the renal physiological function.

Furthermore, nitrobenzene mediated a marked increase in potassium ion concentration in the serum. Potassium ion is the major cation of the intracellular fluid, while about $10 \%$ of the total body potassium is also found in the extracellular one. Any changes in the serum potassium ions level are known to have serious health implications like hyperkalemia which is associated with symptoms such as abdominal cramping, fatigue, muscle weakness, paralysis and cardiac arrest $(22,23)$. The treatment with various concentrations of methanol leaf extract of Vernonia amygdalina or Vitamin E significantly decreased the potassium ion level in the serum.
This suggests the protective effect of the extract on peroxidation of the polyunsaturated fatty acids in the membrane which delocalized Na-K ATPase from basolateral to apical membrane resulting in the electrolyte imbalance (24).

The kidney injury is characterized by the elevation of the kidney metabolites (urea and creatinine) in the serum. The observed increase in the serum levels of urea and creatinine after the exposure to nitrobenzene in this study may be a result of leakage of the kidney membrane, excessive protein intake or impairment in the kidney functions $(25,26)$. The urea and creatinine levels were further determined to establish the source of the perturbation. However, the improved renal function following the treatment with the leaf extract suggests the protective effect of Vernonia amygdalina on the kidney. The ameliorative effect of the leaf extracts on the kidney function could be attributed to constituent phytochemicals such as terpenoids (27), saponins (28), flavonoids (29) and tannins with known renoprotective properties. Flavonoids could confer renoprotection against glomerulonephritis, diabetic nephropathy, and chemically induced kidney insufficiency (29).

In this study, the exposure of rats to nitrobenzene caused a marked increase in the level of renal $\mathrm{H}_{2} \mathrm{O}_{2}$. Biotransformation of nitrobenzene has been reported to generate free radicals and reactive oxygen species which in turn, alters the antioxidant system and finally results in the oxidative stress and macromolecule damage (30). $\mathrm{H}_{2} \mathrm{O}_{2}$ can be rapidly decomposed into oxygen and water and this may produce hydroxyl radicals $\left({ }^{\circ} \mathrm{OH}\right)$ that can initiate lipid peroxidation and cause DNA damage (31). However, the treatment with graded doses of methanol leaf extract of Vernonia amygdalina or Vitamin E significantly mitigated the hydrogen peroxide generation in the kidney. This can be attributed to the antioxidant and free radical scavenging effects of the extract. Plants have been proven to be an important source of natural antioxidants and phytochemicals that mitigated the oxidative stress instigated by an increase in free radicals/ROS and help in the treatment of many human diseases.

Similarly, the administration of nitrobenzene to the rats caused a significant increase in lipid peroxidation as indicated by a marked level of MDA in the kidney. Lipid peroxidation has been reported to play a critical role in carcinogenesis (32). The process produces some byproducts which are highly toxic to the cells. These toxic byproducts include MDA and 4-hydroxynonenal. They can easily attack cellular targets such as proteins and DNA leading to genetic mutations and ultimately to carcinogenicity (33). However, the groups treated with graded doses of methanol leaf extract of Vernonia amygdalina or Vitamin E showed a significant reduction in the level of malondialdehyde when compared to the animals treated with nitrobenzene only. The observed decrease in lipid peroxidation in the rats treated with methanol leaf extract of Vernonia amygdalina could be due to its ability to scavenge hydroxyl and peroxyl radicals. 
Nitrobenzene induced an inflammation in the kidney of the experimental rats as evidenced by a marked increase in the level of NO and MPO activity. This observation indicates the involvement of aggravated inflammatory response in nitrobenzene-induced hepatotoxicity. NO is a toxic defense molecule synthesized by inducible nitric oxide synthase (iNOS) in many cell types involved in immunity and inflammation. The treatment with various doses of methanol leaf extract of Vernonia amygdalina or Vitamin E significantly inhibited the inflammatory process in the renal cells. This agrees with the previous report that the extract has anti-inflammatory properties (34).

One of the primary functions of antioxidant and free radical scavenging enzymes such as CAT, and SOD is to protect biological cells against the free radical attacks and oxidative stress. This study revealed that the administration of nitrobenzene caused a significant reduction in the activity of these enzymes in the rats. The observed reduction in these enzymes activities may be a result of overwhelming detoxification activities of the enzymes by conjugating with the free radicals/ROS and other toxic by-products to enhance their excretion. However, there was a marked increase in CAT, and SOD in the rats treated with graded doses of methanol leaf extract of Vernonia amygdalina or Vitamin E. Many scientific reports have proven that one of the protective mechanisms of actions of plant extracts is via upregulation of these endogenous antioxidant enzymes $(35,36)$.

Furthermore, a depletion in the GSH level was observed in the nitrobenzene treated rats. This significant decrease in the GSH level might have been due to GSH usage by the detoxifying enzyme (GST) and it may be responsible for an increase in lipid peroxidation (37). The free radical mediated tissue damage can be inhibited or alleviated by ensuring the redox balance to decrease the oxidative stress. On the other hand, the rats treated with Vernonia amygdalina or Vitamin E display a marked increase in the GSH level. This agrees with the previous report of Oladele et al (38) who documented that Vernonia amygdalina caused a reversal to the decreased GSH level induced by nitrobenzene. This suggests that the protective effect of Vernonia amygdalina extract involves maintenance of the antioxidant capacity in preventing the renal cells against the oxidative damage.

\section{CONCLUSION}

The result from this study revealed that nitrobenzene induced the renal damage with an evidence of the altered serum electrolyte homeostasis and a significant increase in the serum level of renal metabolites (urea and creatinine). A marked increase in hydrogen peroxide with a concomitant decrease in the GSH level, CAT and SOD activities also confirmed the oxidative stress in the kidney. Furthermore, an inflammation was observed in the kidney with the increased level of NO and MPO with the concomitant increased level of MDA confirming lipid peroxidation. However, the treatment with various concentrations of methanol leaf extract of Vernonia amygdalina reversed all the nitrobenzene- associated renal injury, oxidative stress, lipid peroxidation, inflammation and altered antioxidant defence system. Similarly, histological observations showed that the extract was capable of not only preventing but actually reversing pathomorphological changes of the nitrobenzene-induced kidney injury such as mild fibrosis and hemorrhage characterized by presence of red inflammatory cells. Taken together, methanol leaf extract of Vernonia amydalina exhibited the renal protection which may be beneficial for the treatment and management of kidney diseases or other related disorders via enhancing the serum electrolyte homeostasis, protecting the structural integrity of the kidney, antioxidant, anti-inflammatory mechanisms.

\section{REFERENCES}

1. Wang H, Naghavi M, Allen C, et al. Global, regional, and national life expectancy, all-cause mortality, and cause-specific mortality for 249 causes of death, 19802015: a systematic analysis for the global burden of disease study 2015. Lancet. 2016; 388: 1459-544.

2. Joy J, Nair CK. Amelioration of cisplatin induced nephrotoxicity in Swiss albino mice by rubia cordifolia extract. J Can Res Ther. 2008; 4: 111-115.

3. Cattley RC, Everitt JI, Gross EA. Carcinogenicity and toxicity of inhaled nitrobenzene in $\mathrm{B} 6 \mathrm{C} 3 \mathrm{~F} 1$ mice and F344 and CD rats. Toxicol. Sci. 1994; 22: 328-340.

4. Howard PC, Beland FA, Cerniglia CE. Reduction of the carcinogen 1-nitropyrene to 1-aminopyrene by the rat intestinal bacteria. Carcinogenesis. 1983; 4: 985-990.

5. International Programme on Chemical Safety (IPCS). Nitrobenzene environmental health. criteria 230 . Geneva: WHO 2003.

6. Kumar GP, Khanum F. Neuroprotective potential of phytochemicals. Pharmacogn Rev. 2012; 6: 81-90.

7. Kigigha LT, Onyema E. Antibacterial activity of bitter leaf (vernonia amygdalina) soup on Staphylococcus aureus and Escherichia coli. Sky J. Microbiol. Res. 2015; 3 (4): $041-045$.

8. Owen JO, Amakiri AO, Karibi-Botoye TA. Lipid - lowering effects of bitter leaf (vernonia amygdalina) in broiler chickens fed finishers' mash. Agric. Biol. J. North Am. 2011; 2(6): 1038-1041

9. Achuba FI. Evaluation of the protective effects of bitter leaf (vernonia amygdalina) on haematological indices of rats fed with crude oil treated diet. Jasem. 2018; 22 (4): $489-492$.

10. Oladunmoye MK, Afolami OI, Oladejo BO, Amoo IA, Osho BI. Identification and quantification of bioactive compounds present in the plant vernonia amygdalina delile using GC-MS Technique. Nat Prod Chem Res. 2019; 7: 356-361.

11. National Research Council (NRC). Guide for the care and use of laboratory animals 8th Edition. The National Academies Press. 2011. 
12. Lowry OH, Rosenbrough NJ, Farr AL, Randall RJ. Protein measurement with the Folin phenol reagent. Journal of Biological Chemistry. 1951; 193: 265-275.

13. Green LC, Wagner DA, Glogowski J, Skipper PL, Wishnok JS, Tannenbaum SR. Analysis of nitrate, nitrite, and $[15 \mathrm{~N}]$ nitrate in biological fluids. Anal. Biochem. 1982; 126: $131-138$.

14. Granell S, Gironella M, Bulbena O, Panes J, Mauri M, Sabater L, Aparisi L, Gelpi E, Closa D. Heparin mobilizes xanthine oxidase and induces lung inflammation in acute pancreatitis. Crit. Care Med. 2003; 31: 525-530.

15. Misra HP, Fridovich I. The role of superoxide anion in the autoxidation of epinephrine and a simple assay for superoxide dismutase. J. Biol. Chem. 1972; 247: 31703175 .

16. Varshney R, Kale RK. Effect of calmodulin antagonist on radiation induced lipid peroxidation in microsomes. International Journal of Radiation Biology. 1990; 58: 733-743.

17. Buetler E, Duron O, Kelly BM. Improved method for the determination of blood glutathione. Journal of Laboratory and Clinical Medicine. 1963; 61: 882-888.

18. Clairborne A. Catalase activity. Handbook of Methods for Oxygen Radical Research. CRC Press, Florida. 1995.

19. Wolff SP. Ferrous ion oxidation in the presence of ferric ion indicator xylenol orange for measurement of hydroperoxides. Methods Enzym. 1994. 233, 182-189.

20. Yolanda S. Electrolyte Disturbance and Acute Kidney Failure. Merck \& Co., Inc.,Kenilworth, 2019.

21. Oladele JO, Oyewole OI, Bello OK, Oladele OT. Modulatory properties of Telfairia occidentalis leaf extract on pancytopenia, electrolyte imbalance and renal oxidative damage in rats. J. Biosci. Biotechnol. Discov. 2017; 2: 74-78.

22. Enemor VH, Okaka AN. Sub-acute effects of ethanol extract of sarcocephalus latifolius root on some physiologically important electrolytes in serum of normal wistar albino rats. Pakistan Journal of Biological Sciences. 2013; 10: 3923.

23. Biff FP. Angiotensin converting enzyme inhibitors and angiotens inreceptor blockers: what to do if the serum creatinine and/or serum potassium concentration rises. Nephrol Dial Transplant. 2003; 18:1973-197.

24. Oladele JO, Oyewole OI, Bello OK, Oladele OT. Cadmium chloride induced electrolyte imbalance, pancytopenia, oxidative stress and renal damage: ameliorating effects of aqueous extract of telfairia occidentalis. Int $\mathbf{J}$ Pharmacognosy. 2017; 4(7): 232-237.

25. Oladele JO, Oladele OT, Ademiluyi AO et al. Chaya (jatropha tanjorensis) leafs protect against sodium benzoate mediated renal dysfunction and hepatic damage in rats. Clin Phytosci. 2020; 6: 13.

26. Oyewole OI, Oladele JO. Changes in activities of tissues enzymes in rats administered ficus exasperata leaf extract. Int. J. Biol. Chem. Sci. 2017; 11(1): 378-386.
27. Dong L, Luo Q, Cheng LZ, Yan YM, Cheng YX, Wang SM. New terpenoids from resina commiphora. Fitoterapia. $2017 ; 117: 147-153$.

28. Chen M, Long Z, Wang Y, Liu J, Pian H, Wang L, Chen $Z$. Protective effects of saponin on a hypertension target organ in spontaneously hypertensive rats. Exp Ther Med. 2013;5(2):429-32.

29. Félix-Vargas F, Romecín P, García-Guillén AI, Wangesteen R, Vargas-Tendero P, Paredes MD, Atucha NM, García-Estañ J. Flavonoids in kidney health and disease. Front Physiol. 2018; 9: 394.

30. Howard PC, Beland FA, Cerniglia CE. Reduction of the carcinogen 1-nitropyrene to1-aminopyrene by the rat intestinal bacteria. Carcinogenesis. 1983; 4: 985-990.

31. Sahreen S, Khan MR, Khan RA. Phenolic compounds and antioxidant activities of rumex hastatus $\mathrm{d}$. don. leaves. J Med Plants Res. 2011; 5: 2755-2765.

32. Banakar MC, Paramasivan SK, Chattopadhyay MB, et al. 1-alpha, 25-dihydroxyvitamin D3 prevents DNA damage and restores antioxidant enzymes in rat hepatocarcinogenesis induced by diethylnitrosamine and promoted by phenobarbital. World J Gastroenterol. 2004; 10: 1268-75.

33. De Zwart LL, Meerman JH, Commandeur JN, et al. Biomarkers of free radical damage applications in experimental animals and in humans. Free Radic Biol Med. 1999; 26: 202-26.

34. Ibrahim G, Abdurahman EM, Ibrahim H, Ibrahim NO. Comparative cytomormological studies on the studies of V. amygdalina Del. and V. Kotschyama. Nig. J. Botany 2010; 23(1): 133-142.

35. Farombi EO, Awogbindin IO, Farombi TH, Oladele JO, Izomoh ER, Aladelokun OB, et al. Neuroprotective role of kolaviron in striatal redo-inflammation associated with rotenone model of Parkinson's disease. Neurotoxicology. 2019; 73:132-141.

36. Oyewole OI, Oladele JO, Oladele OT. Methanolic leaf extract of ficus exasperata leaf attenuates arsenate-mediated hepatic and renal oxidative stress in rats. Res. J. of Health Sci. 2017; 5(2): 115- 123.

37. Bansal AK, Bansal M, Soni G, et al. Protective role of Vitamin E pre-treatment on N-nitrosodiethylamine induced oxidative stress in rat liver. Chem Biol Interact. 2005; 156: 101-11.

38. Oladele JO, Oyeleke OM, Oladele OT. et al. Nitrobenzene-induced hormonal disruption, alteration of steroidogenic pathway, and oxidative damage in rat: protective effects of Vernonia amygdalina. Clin Phytosci. 2020; 6:15. 